\title{
THE REPUDIATION OF REPRESENTATION IN PLATO'S REPUBLIC AND ITS REPERCUSSIONS
}

This paper surveys a selection of texts from the fourth century B.C. to the ninth century A.D. and considers the continuing repercussions of Plato's famous attack on art for the present as well as the past. I propose to treat the subject in five sections:

1. A brief consideration of the iconoclast controversy of the eighth and ninth centuries A.D., to highlight the theory behind the iconoclasts' rejection of pictorial art from the Church (and effectively from society).

2. A general discussion of Plato's apparently iconoclastic argument in Republic 10 , to suggest that it too, like the later iconoclasm, was rejecting certain implicit claims made about the value of representation as such.

3. A closer analysis of the arguments in Republic 10 to clarify precisely what theories of art are vulnerable to them.

4. A survey of some subsequent defences of art on the basis that it imitates nature, to show that Plato was right to say that a defence on those lines would not make art sufficiently important to justify the place we accord it in society (or the Church).

5. Turning back to the iconoclastic controversy, I shall take up and press further an argument that assigns to art a role not of imitating an independent reality, but of incarnating reality in an available form. I shall suggest that this is a more promising line to look at in seeking a justification for art's place in society, and indeed that Plato himself may prompt us to take that view. If this is so, Republic 10 becomes a critique of the copy/model analysis of art and casts a question mark over the classic middle period theory of forms. The starting point and the conclusion of the paper must be the claim that Republic 10 is not an appendix but a frame; it changes the way we read the Republic as a whole, and we cannot afford to ignore it and still say we understand what Republic 2 to 9 are about.

Twelve hundred years ago, in A.D. 787, the seventh ecumenical council at Nicea declared that it was alright to have pictures in churches. Iconoclasm is usually traced back to the year 726 and the emperor Leo III, while looking forward, it 
continued beyond 787 and well into the ninth century; but many of the arguments for and against images had been around in the pagan schools long before 726 .

In choosing to look at the theoretical arguments I am ignoring the social and political explanations that might be offered for iconoclasm, not because they are unimportant but because they are not relevant to my present concern. On the theory side, scholars generally concentrate on the issue of idolatry, with some justification, since idolatry is the charge frequently brought by iconoclasts against those who venerate images. The charge was that worship was paid to the wood and stone of which images were made; simple folk, it was claimed, worshipped the wooden form before them, not the god it stood for.'

On the question of who ought properly to receive honour, the god or the material object, there cannot have been real disagreement. But there is a related question which lies behind the charge of idolatry, and that is how the material object can stand in for the god. Images were defended on the grounds that the honour passes to the god, but what if the image does not, or cannot, accurately represent the god? It is not sufficient to show that we are honouring something other than the image - it had better be the right 'other', a correct concept of the true god. We need to explain the relationship between the image and the god, and also the rôle of the viewer.

The supporters of images go some way to meeting this challenge, but not very far. For the most part old time-honoured arguments from the pagan schools are trotted out in a boring way, with a few favourite quotes from St Basil and other Church worthies. Two arguments, however, merit attention. One, which I shall call the 'incarnation argument', is the most interesting and original; the other is the 'symbolism argument'.

The incarnation argument depended on stressing the fact that we live after the incarnation: God's relationship with the material world changed when he became man, and one feature of his manhood was that it was capable of being depicted; human beings are fundamentally depictable. Hence God has become available for depicting. This is fine as an argument to show that accurate icons are a theoretical possibility, but if we are seeking an assurance that the icons we have are accurate representations of the incarnate Christ it seems inadequate. We need, it seems, to supply another argument to show that an accurate likeness actually exists, ${ }^{2}$ or that the incarnation argument does not depend on accurate likeness to the historical Jesus. I shall return to this possibility at the end of the paper, in section 5 .

The symbolism argument is not new but can be traced back to Stoicism and even earlier. ${ }^{3}$ It claims that images work as symbols to point to a reality which may differ fundamentally from the symbol used to remind us. This avoids the problem that it seems impossible to represent gods adequately in material forms, but it gains nothing substantial for the iconophiles who need a justification for likenesses, not just symbols. The issue is not about representing Christ with the 
Chi-rho, or a cross or as a lamb in symbolic form $;{ }^{4}$ that is neither what the iconoclasts attacked nor what the iconophiles were defending. They needed a defence of images of a mimetic nature, images that claimed to represent Christ as man.

This brief glance at the iconoclastic controversy suggests that both sides had a naive view of the rôle of the viewer in relation to a picture: a picture works in so far as it presents an accurate likeness, and the viewer is expected to take at face value whatever the picture presents. The viewer's role is passive; the success of the picture depends upon the quality of the picture (its relationship with what it is a picture of) and not on a response from the viewer. And the relationship of the picture to what it is of seems to be a sort of copying.

Plato is often regarded as an enemy of art and literature, and particularly of any that involves copying or imitation. In the last book of the Republic he mounts an argument against art in general: poiesis is his subject and although he is particularly concerned about verse poetry, it is impossible to salvage prose literature or the visual arts from his attack. ${ }^{5}$ Book 10 is the last book. Plato stops us in our tracks; we cannot go any further (indeed it is not clear that we can complete book 10: what after all is the status of the Myth of Er?) and we certainly cannot leave our view of the earlier books unrevised. You cannot accept the iconoclastic argument of book 10 and still take home the icon of the perfect state painted in books 2 to 9 .

The Republic sits in a frame between book 1 and book 10 which together demand that it justify itself. ${ }^{6}$ What is the value of the dramatic dialogue with its make-believe account of a fictional conversation, its motley characters and the ideal they pretend to describe? Republic 1 fails to meet the criteria of book 3 that the characters presented should be worthy models for the young to imitate, and the whole work seems to fail the broader criteria of book 10 , that we should seek real things not pretty descriptions of them.

The Republic's self-referential demand for a justification for works of art raises the question of what sort of justification we might expect to offer for representational art or drama. Republic 10 may appear at first reading as an attack on representational art, but a moment's consideration will show that what it attacks is a certain critical theory about what art offers to society.

\section{Mimēsis}

Plato is considering art on the basis that it is mimetike, and the meanings of mimèsis and mimetike which are so central to his objection have been much discussed. I do not propose to determine exactly what Plato means by these 
words; rather I shall use a variety of English terms in a haphazard way to convey the Greek words related to mimesis, including copy, imitation, representation, fake, make-believe, pretend and portray, translating in each case according to context and/or whim. I have in any case no interest in distinguishing 'good' and 'bad' forms of mimésis as some scholars have tried to do, since I am proposing to agree with Plato that whatever we mean by mimessis it will not be a good justification for the place of art in society. Basically mimesis involves the notion that prior to making a work of art the artist must have a more direct and independent experience of the original which he then depicts; and that the potential viewers also could, in principle, see the original more directly independently of the art that portrays it.

Plato, or rather the Socrates of the Republic, offers arguments against three claims that might be made for art on the basis of imitation. Before springing to the defence of art we should consider what theories are under attack and whether we need regret their loss.

Two possible accounts of the strategy of Republic 10 should be compared. One, the usual one, goes like this:

Plato thinks poetry, as well as painting, essentially involves imitation. He sees imitation as positively harmful. His arguments in Republic 10 attack art on the grounds that its imitative quality is detrimental. Any defence of art would need to prove it had benefits to outweigh the harmful effects of imitation, and Plato cannot actually envisage such a defence, although Socrates is made to long for one.

The alternative, which I prefer, goes like this:

Plato holds that anything allowed in the ideal state must be justified by a positive value to society. Seeking the justification for art, he found that current critical theory had only the notion of imitation to offer. He considers and rejects three possible attempts at locating art's value for society in its ability to imitate nature. Nevertheless poetry's case is not closed since a justification on the basis of some other value is still a possibility. The fact that imitation cannot justify art does not mean that art that looks, or is, imitative cannot be justified, though as yet Socrates has not found a justification for it.

Here we can see that the claim that imitation itself can be harmful is part of the argument that imitation can never be a good justification for art, rather than an argument against art itself. Plato's main argument is demonstrating that art lacks a good defence, rather than that art itself is harmful. Socrates invites a lover of poetry to supply the defence it lacks, to show that it is not only pleasant but also 
useful to society and human life. ${ }^{7}$ He does not ask that the charges brought against imitation should be denied.

Socrates' opponent is not on the scene in Republic 10. Glaucon is there, but he is a yes-man. The only real antagonist is Socrates himself, Socrates the lover of poetry and tragedy, who longs to find an alternative defence to give poetry a place in his ideal. ${ }^{8}$ Socrates never admits final defeat for this hope, but he does concede defeat for the claim made on behalf of poetry so far.

There is no professional art critic to state his case in Republic 10; but in the Ion Plato does offer a literary critic a chance to say what is good about good poetry. At least we might expect Ion to give us an explanation of why Homer is better as a poet than Hesiod or anyone else, and this would perhaps have indicated some critical theory about what makes poetry good. But Ion never gets that far since he is immediately exposed to Socrates' ridicule; given that Ion knows nothing about poetry other than Homer, he is not in a position to judge that Homer is better than the others of whom he knows nothing. ${ }^{9}$ Ion is not qualified to make theoretical judgements about poetry in general. Nor is Ion qualified to judge Homer's qualities as a teacher of practical or technical skills, since, Socrates argues, in every case there are professional experts who would be qualified to judge Homer's teaching while Ion himself disclaims professional expertise in anything other than generalship (in which also he has no proven ability).$^{10}$

The first and third parts of the Ion show in this way that the professed critic is not qualified to give a reasoned judgement about the value of Homer's poetry either in terms of its literary merits or its informative lessons. The central section of the dialogue ${ }^{11}$ somewhat ironically offers Ion the option that his enthusiasm for Homer is based not on theory but a kind of charismatic mania. This irrational insight would not provide the reasoned argument for poetry that the Republic seeks (though perhaps it might provide the apology envisaged at 607c3-d4). What the Ion shows is that Ion is not in a position to give any reasoned argument for the value of poetry; but the dialogue does open the question of how poetry could be justified on literary or educational criteria.

In the Ion some indication is given of the areas in which Socrates might expect the literary critics to seek a justification for poetry: either there is some literary or aesthetic quality to poetry in general, in which case the worth of any particular piece of poetry should be judged by someone expert in poetry as a whole; or there is some non-literary value, a technical expertise that poetry shares with the crafts it describes, in which case the critic needs to be an expert in those skills as a whole and not merely in poetry. In Republic 10 the second issue, concerning technical expertise, appears again, and something resembling the first issue arises in connection with the idea that poets have a particular expertise in arousing 
emotion. ${ }^{12}$ However the Republic adds to the Ion by seeking a justification for these claims in the notion of mimesis, the copying of nature. Ion the critic had gone along with Socrates' account of how to judge art for its merits, but he had failed notoriously to produce a theory of why Homer is a good poet, or why Homeric poetry can teach us about generalship. In Republic 10 Socrates fills that gap with the suggestion that art copies the independent reality we call nature.

We do not need to suppose that Plato (or Socrates) invented the notion of mimesis; indeed the argument makes more sense if mimesis was a feature of critical theory at the time. What Plato has done is to ask a new question - what justifies the place of art in society? - and to look at the only plausible candidate he could find, namely mimésis. He does not suggest that Ion or the literary critics had actually used the idea that art imitates reality to justify its value for society.

(i) Republic 10 starts by asserting that it must be right to refuse to admit literature that is imitative. Most scholars identify the allusion to an earlier discussion on this subject as a reference back to the discussion of schoolbooks in Republic 2 and $3^{13}$. The discussion of imitation there concerned the extent to which the poet spoke in his own character; here, however, although Plato takes up the issue of mimessis again, a new definition is given and we start entirely afresh. Both Glaucon and Socrates claim that they have not the faintest clue what mimèsis is, at 595 c 7-9. Clearly we are not encouraged to recall an earlier definition. It seems that the direct speech definition of the earlier discussion will be subsumed under the new account but this account goes much further. It is no longer the portrayal of character alone that is at issue, but also the description of man-made artefacts, techniques and skills. This is why literature, and not just drama, becomes vulnerable, and the visual arts can be used to illustrate the problem. Direct speech is not mentioned because it is no longer the distinguishing mark of imitation. Thus despite the back reference, the new passage does not merely repeat a conclusion reached before but looks forward to more farreaching conclusions for a broader definition of mimetic art and for a larger section of society - indeed society as a whole, not just the young guardians.

(ii) Socrates proceeds, at $595 \mathrm{bc}$, to declare his respect for Homer and his belief that Homer was teacher and leader of all the finest tragic poets. We are reminded of Ion's claim (Ion 531d11) ${ }^{14}$ that Homer is a better poet than all the others. But neither Socrates nor Ion can provide a reasoned explanation for the view that Homer is a good poet: Socrates' opinion is based on an old 'love and respect from childhood', 595b10, and it is insufficient to combat reasoned arguments that will get at the 'truth', 595c2-3.

(iii) What is mimesis, asks Socrates at 595c7, and the answer comes in terms of Forms and particulars and imitations of particulars. It might seem that this is to give mimetic art its death-wound with the first blow, since if we start by making the theory of forms axiomatic, and the theory of forms brings the consequence that originals are better than copies, and the more direct perception of the form 
better than the more indirect, then it seems to follow automatically that works of art that are copies of real life are bound to come out inferior to real-life objects. Mimesis, it seems, could not justify anything if mimessis is defined in this way.

This impression would be over-hasty for two reasons.

1. It is not simply the theory of forms that gives this result. Excluding the theory of forms from the discussion would not necessarily give imitation a better justification. What lies behind the difficulty is the assumption that mimetic art is there to teach us facts about a world we know independently; we can exclude the mention of forms and still see that if everything represented in art is also available for us to see directly without artistic copies, and we are supposed to learn true facts about the real originals from looking at the copies, it seems that we are better off looking at the originals. The first objection to mimesis therefore attacks the notion that art is valuable for its information about objects in the real world. 2. Nevertheless we must still see that a defence along these lines would be possible even while maintaining the theory of forms and acknowledging that independent access to the original is better than the copy. It is no accident that Plato's first criticism of art begins by considering the effect of a mirror reflecting an image of things in the world, 596de, and goes on to consider a painter who paints a picture of a bed. In the case of the bed it seems absurd that we should need to look at a painting of a bed when there are plenty of good solid 3D beds for us to see all around, while the mirror can only reflect objects when of necessity they are present for more direct inspection - unless, that is, you are using the mirror as a periscope in which case you may be glad of information not otherwise available. Plato does not consider art which portrays something not currently available in real life. If we look to the Phaedo ${ }^{15}$ we find that a likeness of Simmias can remind us of Simmias in his absence, however, and it is no distance from there to some later defences of religious art in particular. If the real thing is not currently available for us to see, a picture may serve to remind us. We shall return to Maximus of Tyre's defence on these lines in section 4.

(iv) Having defined mimessis as copying the everyday particulars, Socrates first suggested that a real bed would be better than a painting of a bed for conveying information about beds. Clearly this leaves open the possibility that the artist might portray something to which we had no independent access. In the case of the gods we may need statues, however inadequate they are as likenesses. But for this to be plausible as a defence it seems that the artist must have some greater expertise than we do on the subject in question; if the statue is to help us to know something we could not otherwise know, the craftsman ought to know something more than we ordinary folk, it seems. And if the poet is to teach morality or generalship, it appears he should be an expert in these subjects.

Socrates proceeds to attack the theory on this score, 598dff. Many people, he says, reckon that Homer and the tragedians are knowledgeable about all skills and about morality and theology, 598de; and they reckon that a good poet must 
speak from knowledge. Is this popular view mistaken, asks Socrates, or is it true that good poets know what they are talking about?

Three reasons are given for denying that the poet is knowledgeable or that poetry can be justified by its expertise in everyday matters.

1. 599a-b. If someone has the capacity to make either the real thing or an imitation of it, anyone seeking a reputation would make the real thing not the fake. So any artist who produces imitations must be doing so because he cannot make the real thing. This follows from defining the artist's task as imitation of a real thing, since the most perfect imitation would be indistinguishable from the original. Hence any artist who produces only poetry or pictures and not the objects themselves must have failed in his task.

2. Socrates objects to the fact that Homer is not himself an expert practitioner of the practical skills he is supposed to teach. He was not himself renowned for medical or political skills in his own day, nor did he have great pupils who learnt from his teaching, 599c-600e. Again we assume that the aim of imitation is to produce at best a real thing, and failing that a fake.

3. Socrates points out that for any subject which the poet or painter represents there are real experts on the use of them in real life; if it is real practice in real life that we need to know about, it is the real practitioners and the real craftsmen to whom we should turn, $601 \mathrm{~b}-602 \mathrm{~b}$.

Given that we are seeking a justification for art on the basis of imitation, all these three objections are reasonable. By definition the work of art is attempting to liken itself to the real thing but not being the real thing, and hence if we seek to gain knowledge of the real thing the likeness will be inadequate and inferior to the original, whether an object or a practice. Art can claim educational value as an imitation of an external reality only if that reality cannot be reached independently; but in that case it is difficult to establish the artist's credentials as an expert in the field. ${ }^{16}$

(v) Having dismissed imitation as a source of valuable technical knowledge Socrates turns to the other defence of art, the enjoyment value of representations of human character. Perhaps the poet has a special expertise in this field. Socrates suggests that a usual criterion for what makes good drama is the convincing representation of other people's sufferings and emotions, and the more emotional and emotive the better. Good poetry appeals not to reason but to emotion, $602 \mathrm{~b} 8,605 \mathrm{c} 10-\mathrm{d} 5$.

This should be a good defence since it evades the issue of whether poetry and art contribute to education of a rational sort. Even if it cannot teach facts and skills it may have a value for the lower parts of the soul. Socrates' attack on this claim is in six steps, starting at $602 \mathrm{~b}$. The rejection is complete at $607 \mathrm{~d}$.

1. Make-believe depends on the least rational part of the soul (602b-603b)

2. Good social behaviour minimises non-rational emotion (603c-605b2)

3 . The appropriate response to art is imaginative, non-rational. (605c10-d4) 
4. The criterion for a good poet seems unreasonable on real life criteria (605de) 5. Reasonable men delight in art because they have a desire to indulge emotions and are led to believe indulgence is reasonable (606a-b5)

6. The real danger lies in the habit-forming effects which affect real-life behaviour.

The first step suggests that if we rank the parts of the personality in order of rationality the make-believe of art seems to depend on a response from the least rational or worst part. Socrates implies that a rational soul would respond unimaginatively to art, but that is not to say that a rational, unimaginative response is appropriate, nor that imitative art is a bad thing. On the contrary in step $3(605 \mathrm{c} 10-\mathrm{d} 5)$ he shows, quite rightly, that the appropriate response is an imaginative one, one that treats the representation as if it were the real thing. This is the response adopted and enjoyed by the best of us, Socrates included (605d), and our criterion for good poetry reflects it. Socrates does not advocate a rationalising approach to art, nor does he reject art because the people in his state will be too stupid to see through it. ${ }^{17}$ Hence it follows that if we are to hold that the make-believe element is of any value we must hold that being taken in by it, in the appropriate way, is also valuable or at least not damaging. The rejection of the value of make-believe in art comes in the demonstration that the non-rational response is not valuable for the good of our character. This comes in steps $2,4,5$ and 6.

Step 2 reminds us that our criterion of good social behaviour involves minimising the response to the emotions of grief and passion and the like while maximising our control over these emotions. The correct response to art implies a different set of values. Step 4 repeats the observation that our criterion for a good poet (ability to get us emotionally involved) contrasts with our real-life values. Hence our praise of the poet, when on real life terms we should be ashamed of him, seems unreasonable.

In step 5 Socrates explains the admiration of poetry in apparently reasonable men as resulting from a reasoned argument of sorts. They have a natural desire to weep over their own misfortunes and are led to relax the guard over these emotions because they reason that if they see a supposedly good man indulging the passions it is alright for them to do so too. They are reluctant to forego the pleasure that results. However as step 6 observes there is only a real problem if a habit sets in with regard to one's own passions, and it is the dangers of habit that few are aware of.

It is clear that steps 2 and 4 merely show that the criteria of value in art are the reverse of the criteria of value in normal life; they do not show that the supposed value of art is not real. But Socrates adds points 5 and 6 which seem to acknowledge that points 2 and 4 are not conclusive. Point 6 locates an area in which art's inversion of the values of the 'real world' seems to bear upon and threaten the real world itself; the chief claim is that our response to art becomes a 
habit which spills over into, or at least alters, our response to real life and hence we cannot keep the two in watertight compartments with independent value systems. This is built upon point 5 , the notion that we have a natural inclination to indulge the emotions which is part of our response to real life as well as to art. Hence the response that takes pleasure in, and values, emotional indulgence is not confined to mimetic art but can occur, and naturally would occur, in real life, if we do not maintain a constant guard.

This means that we cannot argue that the pleasure of mimetic art is a straightforward gain in an area where real-world criteria of good and bad do not apply. It may be true that a purely rational response to art would be wrong, but similarly the response proper to art is wrong (Plato reckons) as a response to the real world. And if it is true that our response to the real world will be modified by our indulgence in art-appreciation then art cannot claim immunity and independence.

The reply to Plato.

Plato has given us an argument in three sections to demonstrate the inadequacy of imitation to justify art's place in society. Iconophiles have tended to be worried by Plato's attack in Republic 10, and rightly so since Plato presents it as an argument for excluding poets and poetry, and probably all visual representational art as well; all poetry, that is, except some very dull and inane hymns which hardly seem worthy of the name poetry. And given the requirement of the Republic that everything should have its proper and essential part to play and not be a drain on resources, the demonstration that mimessis will not provide that sort of rôle for art should indeed look worrying. Clearly there are three types of reply to Plato that would deny the need to exclude art.

1. We could accept that imitation was the place to look for a defence of mimetic art, and attempt to find a value in imitation that did not encounter Socrates' objections, or to take up one of the old defences and show that Socrates' objection was not conclusive.

2. We could accept that representational art involves imitation and that imitation does not provide a good justification in itself, but attempt to show that some other advantageous aspect could provide the justification we seek.

3. We could deny that representational art is in fact an imitation of an independent reality at all, and hence show that Plato's objections are to a false account of art.

Most replies to Plato have been along the first two lines. I propose to consider a few examples and then consider what is different about the third option. 
1. Against the objection that real things are better than copies for teaching we might take up Maximus of Tyre's defence of the need for statues, Discourse II.2. Human beings need statues to enable them to grasp what the gods are like, because our minds (at least for most of us) are not up to perceiving divinity direct. We need a helping hand and the statues perform the function of the faint outline letters made by the teacher of grammar for the children to trace.

Maximus' argument evades Plato's first criticism by taking an example in which we do not seem to have independent access to the original of which the statue is a likeness. It is precisely because we cannot go straight to the gods that we need representations of a sort we can cope with. The likeness may indeed fall far short of the full splendour of the original, as Plato suggested, but as the best thing available it does have some informative, or at least mnemonic, value. And like the grammar teacher's outlines the teaching value of the image depends upon its resemblance to the thing it portrays, however faint that resemblance.

This defence of religious images seems to avoid Plato's rejection of art while acknowledging the inferior status of artistic representation to the original. Nevertheless it will not take us very far since it runs into two objections:

1. It can only justify art in cases where the original is not directly available;

2. Precisely because it is only justified where independent access to the original is not available it needs to be able to show that the artist is imitating the original directly if the value depends on conveying the likeness. The grammar-teacher must himself know the letters that he outlines for his pupils. Hence Plato's second objection that the artist is no expert seems to apply.

In response to the first difficulty we might seek a wider justification for art as a whole by taking up a Kantian position and suggesting that reality as a whole is inaccessible directly. The raw materials of the world are too raw for ordinary mortals just as the gods are inaccessible, and art is a means by which the raw reality is interpreted and categorised for us. We need art to see the world through, and in imitating reality it presents it in a way we can appreciate. Again however we still run into the difficulty of how the artist can perceive directly what others are unable to see. If the process is indeed one of copying the natural world the artist needs to see first and copy what he sees. A justification of the value of mimèsis itself still encounters Plato's second point about the artist's expertise.

Two standard responses to defend the artist as expert in the task of communicating reality are available. The response of the Orthodox icon painting tradition is to suggest that the reputable artist does have an expertise not available to most of us. For (i) he is steeped in a tradition which goes back almost unchanged to the earliest icons and to a time when people did have direct knowledge of the subject (e.g. Jesus Christ and the Virgin Mary), and includes various individual icons authenticated by their miraculous powers; thus by making copies of copies the icon-painter reproduces the original at some remove. ${ }^{18}$ And (ii) he engages in a programme of spiritual exercise and prayer which give him a better direct line to 
God than the rest of us have. Plotinus' response is rather similar though more generalised (the second of his three arguments against Plato at Ennead 5.8.1.3240). It is a view that many scholars have tried to find somewhere in Plato, namely that the work of art does not merely reproduce nature as it is seen but goes back to the form. The true artist would have direct knowledge of the form (like the true craftsman should). Granted this, Plato's strictures on the position of "third place from the truth" are partly defused, though his question of why make a pretend thing and not the real one is still apparently unanswered, at least in the case of man-made artefacts. Nevertheless we are left in both icon-painting and the perfect art of Plotinus with a problem of how to distinguish the authentic art of the expert artist from the poor quality productions that might be made by someone who merely imitated the natural world. And have we found some value for the works of art as such that would not be better conveyed by some other form of teaching by experts? Is it better to have an icon than a sermon from an icon-painter?

2. The second line of defence against Plato is to abandon the idea that art's value is didactic or informative about the things it imitates and seek a value in its ability to communicate emotion. This is the area in which Plato launches his third attack and two defences are possible.

(i) One is to deny that indulging emotions in response to art can be detrimental to our behaviour out of the art context. This approach might claim Aristotle as its ancestor. It aims to reassert the distinction between what is appropriate and correct in real life and what is appropriate in the world of pretend, and perhaps indeed to suggest that the world of pretend forms a safety valve for those responses which have to be suppressed in real life. The value of mimesis is seen as the ability to call up the same emotions as the scene would have evoked in real life. The emotions are real, the scene is pretend, and we deny that there is anything shameful in being 'taken in' or deceived by the life-like imitation presented in art, or in indulging emotions we should restrain in polite society.

(ii) Alternatively, taking a line similar to that of Tolstoy among others, we might suggest that good quality art is that which evokes the finer moods, those we would wish to promote in real life, agreeing with Plato that the effect will rub off in real life. Good art in a society will encourage moods and emotions that are beneficial to society.

Both of these defences seem to have something to recommend them until we look at what the criterion for a good piece of mimetic art is. Not only must it be a deceptively good imitation but it must also evoke the right emotion. If I see a picture which the artist meant to represent as pitiful and it makes me angry instead, it is a failure, no good as a communication device. That piece of art cannot have a place in society because you cannot trust it to do what is required. But then what about other art? Surely it is unlikely that any work of art is effective at communicating the poet or artist's intention to every viewer and 
hearer exactly alike, and the more subtle the art the more varied will be the responses - the more it matters who views it and how she interprets it. Thus while locating a valuable rôle for art in society the critics make it impossible for art to fulfil the role appointed in a reliable and trustworthy way. We might try to argue that it is a failure of the artist if the wrong emotion is evoked; if the artist gets the imitation sufficiently accurate the art will prove reliable; but if so clearly all ordinary art is incapable of achieving that standard. But in general it seems that the theory simply fails to take into account the rôle of the reader or viewer in interpreting art, as well as restricting us to a ghastly selection of trite and sentimental art.

3. The third answer to Plato might be to distinguish ourselves from the prevailing art criticism of his time and accept his demonstration that mimesis itself, the copying of an independent reality, will not provide a justification for art. Rather we might adopt the argument I named the 'symbolism argument' which crops up in the debate about icons in the eighth century as well as earlier. The point is that art symbolises a reality beyond itself. It is true that the symbols employed by art may be representations or copies of things we see in real life but the message it conveys to the viewer or reader is not merely the truth about the thing it immediately resembles, but a further and finer truth not available from everyday objects.

Again we might name Aristotle as an example, if it is correct to say that he suggests that the imitation in tragedy of a particular situation conveys to the audience a universalised truth. Plato himself has a symbolism theory to justify using one's aged parents as images of the gods in Laws 11,930eff, though it is not articulated fully. For a clear statement of a symbolism theory we might take the first fragment of Porphyry's Peri agalmatonn. ${ }^{19}$ Statues are for those able to read them, because art is a code of symbols like writing. It is not surprising that those unversed in the symbolism see the statue as nothing but a bit of wood and assume that the devout are worshipping material objects. The same thing happens if someone unable to read sees an engraved stele - to him it is nothing but a stone, but to one who can read it has a meaning which it communicates.

The symbolism theory clearly makes some progress in moving away from the notion that slavish reproduction of reality will in itself be of value. On this view the mimetic character of art is not its recommendation but just the language it happens to adopt; the symbols the artist uses and the reader is accustomed to interpreting are frequently, as it happens, likenesses of ordinary things. But the realities they represent may be mental images, some of which could not be accurately depicted in material media or in drama.

This view cuts through iconoclastic objections that representing the gods in stone is impossible. Clement of Alexandria's objection that if Praxiteles made an Aphrodite modelled on his girlfriend Cratine then the people are worshipping 
Praxiteles' girlfriend is no longer plausible (if it ever was) ${ }^{20}$ Doubtless Cratine was an excellent model for Aphrodite, providing we are prepared to acknowledge that Aphrodite is represented in a human form that symbolises the characteristics we ascribe to Aphrodite on a divine scale. And in the same way the symbolism theory solves the problems of whether art is concerned with deception and illusion: the distance from the truth ceases to matter if the work is not trying to be, or even to pretend to look very much like, the thing it aims to communicate. Art cannot be accused of deceit, ${ }^{21}$ but nor should our response be to treat it as if it were what it represented.

Here comes the crunch. Symbolism may do very well at explaining how a mere picture or drama can convey something beyond itself to the viewer, and it improves on the simple mimésis accounts in terms of its recognition that the viewer has work to do in response to a work of art; art depends for its effect on a viewer interpreting in accordance with a particular tradition. The theory allows that what the viewer perceives is not determined by the artist, nor by a relationship between the image and the original it portrays, but by a relationship between the viewer (or reader) and the image (or drama). The difficulty, however, lies in two areas.

(i) It fails to explain why we should have symbols that are likenesses at all. Pictorial art deals in visual symbols, and dramatic art in dramatic symbols, but the language of those symbols seems unimportant provided the viewer is familiar with it - dance, for example, and some symbolic visual art seem happily to employ a system which does not depend on a resemblance to everyday reality. Indeed inasmuch as the symbol is not intended to be a deceptive reproduction it might seem better that it should not attempt a likeness at all. For the viewer versed in Christian symbolism it might seem more helpful to depict Christ as the lamb for sacrifice ${ }^{22}$ rather than to attempt a convincing portrait of a human face which should not pretend to be a likeness of the real Christ but might seem to be claiming to be. Against iconoclasm we need to find a value for likeness, not just for unlikeness. ${ }^{23}$

(ii) The appropriate response to symbolic art seems to be restricted to a rather intellectual process of being reminded of the real attributes of the thing that is symbolised. It fails to explain why an appropriate response to art is to become involved, to break down the distinction between art and reality and weep with pity or shout with joy. Why are we not required to stand back and observe sceptically that it is only an actor dressed up like Clytaemnestra? And why should we kiss icons, pray to statues or treat the Eucharist as a sacrifice? The muchrepeated claim that the honour paid to the image recourses to the original is not an explanation in itself but rather a claim that requires explanation. Why should symbols, and likenesses in particular, have this power to pass on the honour to the thing they symbolise? The iconophiles of the eighth century did take up the 
symbolism argument, but they needed more than that to show why the resemblance between image and what it was an image of was not merely incidental, a convenient language for symbolism, but had an important role to play.

\section{Incarnation}

For an answer to Plato it seems we must seek something more than a symbolic rôle for art that might or might not work through a resemblance between signifier and signified. As Augustine ${ }^{24}$ and many others have observed, there are signs of God in nature and in man in general ${ }^{25}$ so where is the special role for art that we need in order to rebut Plato's suggestion that we could do without it?

All the arguments so far have supposed that art works by copying a reality which can be known directly and independently. Either we must be reminded of something we knew already, or at least the artist must have seen something more direct than we have. But need we suppose that we can see the same thing independently and more directly? Surely it could be that neither I, nor the artist of Simmias' portrait, need have seen in an uninterpreted 'real Simmias' the features that I see in him in the portrait. If we see the everyday reality as interpreted and textualised by the culture and language we think and see through, we could not in any case see Simmias as a raw object; even when we see him so-called directly 'face to face' the features we notice and the categories we slot him into are built into our initial perception of him by a whole range of influences in our culture. Art, with the rest of the culture, could be seen as contributing to the way we textualise the world.

Thus it is not that the world which art depicts is available in a more direct form which art attempts to copy. It simply does not exist in a more directly available form. Art is one of the languages through which the viewer reads and interprets a reality moulded by the interaction between artwork and viewer or reader. ${ }^{26}$

If art is not copying an independently available natural world we shall need some other explanation of why it appears to resemble our other views of the world. Why did literary critics of Plato's time and for generations after claim that art dealt in imitation? The answer I am suggesting is that art's resemblance to the world we see is not accidental, but a result of the fact that art is one of the influences on the way we see the world. The relationship of model to copy is reversed, since we model our world on the presentation offered by the arts.

To take an example, the ancient Greek painters generally painted the bodies of men brown and the bodies of women white. The difference is built on a general cultural conception of what women and men are; the cultural view is represented 
in the art which is part of that culture. But the visual portrayal in art of a colour distinction between the sexes serves to reinforce and condition the way people actually saw their women - they would expect their decent women to resemble the pale skinned women of art, and they would notice more keenly the differences of skin colour between those who did and those who did not match up to the expectations conveyed in art. Even if they thought that their art copied the way things really were, it is clearly also true that their art influenced the way they thought things were and the way they turned out to be for them. The observation that art and expectations go along together as a means of drawing the reality into the cultural assessment of it should be sufficient to show that art is not simply mimicking reality but creating and reinforcing it.

The influence of art begins at an early stage. It is difficult to tell what our picture of the world would be like if we had lived in a state which banned those nursery pictures with the flat trees, cotton wool clouds and sheep, kings and queens and fairies in tinsel skirts. It is often easy to see with small children that their expectation of what they will see, and consequently much of what they do observe, is governed by their reading of the world through picture book art. Perhaps equally impressive is the influence of television, arguably our nearest equivalent to ancient popular drama, on what we believe the world outside to be like in reality.

\section{The incarnation theory}

It might seem that none of the ancient responses to the rejection of representational art considered the option that art was not copying reality but shaping the way we see reality. However it is worthwhile looking again at the incarnation theory produced by the iconophiles in the ninth century which I dismissed earlier as failing to answer the iconoclast attack. That is true if we take the argument to be a claim that the Jesus Christ of the first century was incarnate and hence can be portrayed now as the man he was then. This suggested that an acceptable icon would be a perfect likeness of the Jesus of history, and it failed since it could not demonstrate that such a portrait actually existed, even though it could exist.

But supposing the argument is not that Christ was incarnate but that the incarnation is an ongoing event that has fundamentally changed the relationship of God with the natural world. The point is not then that we can copy the onceupon-a-time incarnate Christ but that Christ is now in a position of being currently incarnatable. A picture of Christ is the currently incarnate Christ, not a copy of an old no-longer-existent man. Christ exists incarnate in art (though perhaps not art alone) and he depends upon art (and perhaps ritual and words) for his current incarnation. 
I am not sure that this is what Theodore the Studite had in mind in formulating the incarnation argument; in fact I am fairly sure that he did not spell it out in detail, and in certain passages it seems clear that he envisages that icons of Christ are authoritative in virtue of a tradition transmitting the original likeness of the once-upon-a-time Christ from image to image down to the present day. ${ }^{27} \mathrm{But}$ in Epistle II 36, where the incarnation theory is considered in some detail, the objections envisaged by Theodore from his iconoclastic opponents suggest that the incarnation theory goes much further. Asterius (an iconoclast) asserts that you should not draw Christ because the humiliation of the original incarnation is sufficient. ${ }^{28}$ It seems that Asterius regards painting Christ as re-doing the incarnation. Theodore's reply comes in five parts: ${ }^{29}$

1. If art reiterates the earlier incarnation and humiliation, then to suggest that the reiteration is shameful and to be avoided implies that the first incarnation was shameful.

2. The first incarnation was, as Asterius says, freely chosen on God's part, and what is freely chosen is glorious and not shameful as involuntary humiliation would be.

3. If graphic representation reiterates the original event, why does not Asterius reject audible memorials as well as the visible ones, given that they are analogous. 4. Depicting the cross does not mean that there are as many different crosses as there are pictures of the cross, nor does writing out a copy of the Gospel result in a plethora of Gospels. Similarly there is not a second Christ if we depict Christ. 5. We can never have our fill of hearing the Gospel or seeing the visible manifestation of the incarnation. Asterius should not forbid the means of manifesting the salvation of the world.

Of these five points against Asterius all but the fourth start by accepting Asterius' claim that representing Christ should be seen as re-doing the humiliation of the incarnation, but question the inference that such a reincarnation would be unseemly or that it must be rejected. The fourth objection seems to argue that picturing Christ does not amount to a second incarnation; but Theodore is not denying that Christ is incarnate, or re-incarnated, in the picture. Rather he points out that there is not a new and different Christ for every different representation of him. It is the same Christ as in the first incarnation. The point of this may be to deny that there would be any further humiliation involved in the repetition of the incarnation; rather the original incarnation put Christ in his present relationship with matter and new images are merely continuations of an ongoing incarnation-situation, the ongoing vulnerability of one and the same God.

Theodore's view of icons as manifesting the lasting effects of the new relationship between God and the material world is clearly intended as an account of the value of a small group of art-works, particularly images of Christ, though it includes a view on the analogous relation of the sacred text to the Word 
incarnate. Nevertheless it should be possible to extend the theory to form a general theory of visual and literary arts. The reason why God can properly be a subject for images is because God has now become part of the range of things that we expect to incarnate themselves in material images. Other things, after all, we have always assumed could have images. What might it mean to say that ordinary things are incarnated in the visual images we see? Perhaps this would be a way of saying that our perception of reality is as direct through art-works as it is through any other sort of cultural symbol that presents the world to us in a way we can understand. If things are incarnate in the material world, things are just as incarnate in pictures - just as Christ was incarnate as man and is incarnate in art: we can break down that distinction between our direct experience of 'real things' and the art which is just a 'copy'; if reality exists in the art work just as much as in the 'real world' there is no sense to claiming that one must be more real or prior to the other. We are allowed after all to treat the picture as the real thing: to kiss the icon and weep with those on stage.

Plato, on this view, was right to see art as dangerous and influential, and to suggest that the effects of art rubbed off on real life. If we are right to suggest that reality resembles art precisely because art forms part of the linguistic and cultural system that governs the reality we see, then it is right to see the rôle of art as profoundly significant in setting up an ideal society. And it should be clear from my analysis of Republic 10 that there is no reason to think that Plato thought he had shown art to be trivial ${ }^{30}$ rather he has shown that if (a) we accept that art copies reality and (b) we accept the theory of forms and the inference that copies are inferior to originals, then it follows that either art is trivial and useless or art is dangerous in encouraging preoccupation with inferior things. Two possible responses would restore art to the position of importance that Plato clearly assumes it has. Either we can reject the first premise and suggest that art does not copy reality or we can reject the theory of forms that is the basis for supposing that copies are not valuable. However, rejecting the theory of forms may not be sufficient since, as I suggested above, it may still be true that copies of everyday things have no inherent value or importance. Thus the more promising course is to question, as I have just been doing, the notion that art's resemblance to the everyday world we know is a matter of copying.

If Plato believes art is more important than the mimessis theory allows, what evidence is there that might suggest he would prefer the incarnation theory? If we turn to the last words of book 9 of the Republic, immediately before turning to attack the notion of mimésis, Socrates and Glaucon have a little debate about the value of the city they have been building in words; Socrates speaks for a moment as if the perfect city really existed - in fact he has spoken like that most of the time; but at 592 a 7 he distinguishes it from everyday cities: the man of sense would gladly take part in politics in his own city (that is the perfect city) though 
not perhaps in the one he was born into. Glaucon is struck by the realism of Socrates' words. "I understand," he says, "in the city we have just gone through

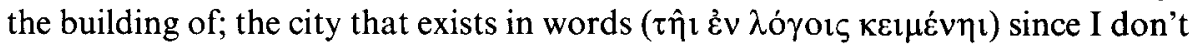
think it is anywhere on earth."

Glaucon wants to draw a distinction between cities that exist on earth and cities built in words; he finds it slightly surprising that Socrates speaks as if it were real. Socrates then justifies himself with two alternatives; firstly it is possible (perhaps, $\imath \sigma \omega \varsigma$ ) that a paradigm exists up in heaven for anyone who wants to to look at and build it (on earth) himself; but secondly, on the other hand, it makes no difference whether it either is anywhere or ever will be (in heaven or on earth). The justification for speaking of the city they have founded as real does not depend on the truth of the theory of forms to provide a model, nor on the existence either now or ever of a model on earth. Most importantly Socrates does not claim that the city they have built in words has been modelled on a vision of any independently existent city. The city they have founded in the discussions of Plato's Republic is not an imitation of a real city, and yet it is a city they have built and can be spoken of in the same terms as a real city. It may be no accident that Plato defends the writing of a Republic in words without recourse to the notion of mimesis, immediately before he launches into his rejection of mimessis as a justification for any art.

What then have Socrates and Glaucon done to the perfect city, if they have not copied it? They have founded or built it (oiki $\zeta o v \tau \varepsilon \zeta, 592 \mathrm{a} 10$ ) and now it is set up

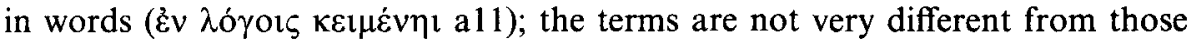

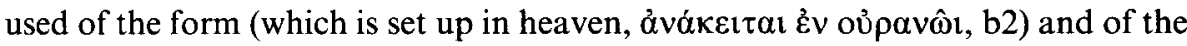

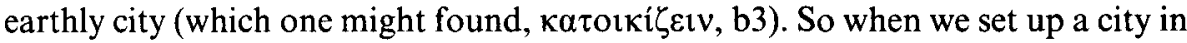
words we do just the same sort of thing as we might do if we set it up in 'reality', and Plato seems to find no difficulty in speaking of the two in exactly the same terms.

If Plato is right, then, we have good justification for venerating the images of the gods as if they were the gods they stood for, and we are right to enter into the spirit of drama and poetry and break down the distinctions between 'art' and 'reality'. The icon may indeed be as direct an incarnation of God as Jesus the man was, whether or not it accurately resembles the Jesus of the first century. Icons may also have a decisive role in determining our notion of what God incarnate looks like: an influential and dangerous role, but not an unjustified one. If we cannot see God more directly than we do through the icons there is no sense in judging the image of God in the icons inferior to some other superior form of representation. We cannot judge the success of icons by reference to a direct vision, just as we cannot judge Plato's Republic as an image of a reality we know independently. It is by no means clear either to Plato or to us that there is a better way of knowing Plato's ideal city than in the words of the Republic. Without the 
Republic we should not see the city as we do, nor should we be better off for not seeing it.

NEW HALL, CAMBRIDGE

CATHERINE OSBORNE

\section{NOTES}

1. The charge goes back to the Old Testament, e.g. Exodus 20.4-5: You shall not make yourself a graven image, or any likeness of anything that is in heaven above or that is in the earth beneath, or that is in the water under the earth; you shall not bow down to them or serve them.

2. For an example of such an argument see Theodore the Studite Ep. 2.8 (P.G.99, 1132C), where he suggests that there is a continuous succession of images from the time of Christ. Cf. also John Damascene, Letter to Theophilus P.G. 95, 352A.

3. See A. H. Armstrong, 'Some comments on the development of the theology of images' Studia Patristica IX (Texte und Untersuch. 94) Berlin 1966.

4. Cf. Canon 82 of the council of 692 , quoted by Theodore the Studite at Ep. 2.8, 1136C. This decree asserts that Christ must be depicted in human form rather than symbolised as a lamb, for example.

5. I am particularly concerned with book 10 here. The earlier discussion of literature in books 2 to 3 centred on the distinction between direct and indirect speech (which implicitly raises a problem about the dramatic dialogue form of the Republic itself and Plato's other works). In Republic 10 the definition of mimesis is new, 595c7, and locates a problem in the copy/model relationship, disregarding any difference between direct or indirect speech. Again a problem implicitly arises for the Republic, not because of its dramatic form but because it claims to portray the (ideal) Republic. Any literature or art which claims to portray an external reality in any form, dramatic or otherwise, seems to be vulnerable.

6. Are we allowed to take Plato's arguments as self-referential? Within the Republic itself the justification for doing so is (i) the very obvious difficulty of special pleading on Plato's behalf against the generality of the arguments about literature, and (ii) the discussion at the end of book 9, $592 \mathrm{ab}$, which raises the question of the relationship of the city portrayed in the Republic to any real instantiations of it. (See further on this passage in section 5 below). In other dialogues Plato does include his own work in critical discussions of literature. See especially Phaedrus 277d-278a where the discussion of the value of writing is explicitly extended to cover all types of written composition in prose or verse, and Laws $7.811 \mathrm{c}-812 \mathrm{a}$, where the conversation in the Laws itself is treated as an example of the type of literature (again prose or verse) to be recommended.

7. $607 \mathrm{~d} 8-10$.

8. $607 \mathrm{bc}, 607 \mathrm{~d}, 607 \mathrm{e}$.

9. Ion $531 \mathrm{a}-533 \mathrm{c} 8$.

10. $536 \mathrm{~d} 8-541 \mathrm{~d} 5$.

11. $533 \mathrm{c} 9-536 \mathrm{~d} 3$.

12. $602 \mathrm{~b}-605 \mathrm{e}$. 
13. For the suggestion that other sections of the Republic might be meant see A. Nehamas, 'Plato on imitation and poetry in Republic 10', in J. Moravcsik and P. Temko (eds.) Plato on Beauty, Wisdom and the arts (1982) 47-78, esp. 52.

14. Prompted of course by Socrates, $531 \mathrm{~d} 10$ and of. $530 \mathrm{~b} 10$.

15. $73 e 9$.

16. On possible ways of justifying the artist's expertise see below, section IV.1.

17. At $595 \mathrm{~b} 6$ Socrates implies that the problem with art is that most people have not the pharmakon, the ability to see that art is just pretence. Nevertheless we see now that even if you can see art for what it is it still lacks a justification - why have mere pretence in society? More than ever it seems to have nothing to offer. Compare Socrates' rejection of a rationalising response to myth at Phaedrus 229c230 a. It is more helpful to take the myths as what they claim to be and see what we can learn that way.

18. Cf. Theodore the Studite Ep. 2.8, 1132C.

19. Apud Eusebius, Praeparatio Evangelica, III.7.1; J. Bidez, Vie de Porphyre (1913) 1*.

20. Protrepticus 4.53 .5

\section{Cf. Clement Protrepticus 4.57.5ff}

22. The Quinisext council of 692 repudiated the symbol of the lamb and recommended portraying Christ in human form on the grounds that it was more effective at calling to mind the relevant doctrines. See above, note 4.

23. It is not only icons which, in the Christian tradition, employ likeness and demand a breakdown of the distinction between the symbol and what it stands for. The drama of the Eucharist works in the same way and expects a similar response.

24. E.g. De doctrina Chr. II 1.1-2; Lib 83 QQ, Q 74 (P.L. 40. 85-6).

25. Cf. Plato's suggestion that parents be treated as statues of the gods, Laws 11, 930eff.

26. The analogy here between art and language moves art onto a different plane from the analogy between art and the written symbols in which language is recorded, as it appears in the ancient examples (e.g. Porphyry, Peri agalmatōn fr. 1 and Maximus Tyrius II 2). But compare also Theodore the Studite Ep. 2.36, where the analogy is between visual images and the Gospel accounts of Christ whether spoken (P.G. 99. 1212 C 13-14) or written (1212D5-1213A3).

27. E.g. Ep. 2.8 , P.G. 99,1132 C.

28. Ep. 2.36, P.G. 99, 1212 B-C.

29. P.G. 99,1212 C-1213B.

30. For the claim that Plato wanted to prove that art is trivial see J. Annas, 'Plato on the Triviality of Literature' in Plato on beauty, wisdom and the arts, 1-28. 